\title{
Spontaneous Growth Hormone (GH) Secretion in an Eight- Year-Old Boy with Cushing's Disease
}

Hans-Reinhard Heise, Klaus Mohnike, Reinhard Unglaub, Dirk Bretschneider and Norbert Bannert

Departments of Pediatrics, University of Magdeburg ( $H-R H, K M, D B, N B)$ and University of Gottingen (RU), Germany

Key words: spontaneous GH secretion, cushing' s disease, growth, IGF-I

\section{Introduction}

Impaired linear growth in children with Cushing's disease results mainly from inhibited insulin like growth factor I (IGF-I) bioactivity, decreased type 1 collagen synthesis and suppressed growth hormone (GH) secretion (1).

\section{Case Report}

An 8 2/12-year-old boy was referred because of excessive weight gain of $13 \mathrm{~kg}$ within 15 months. Height was at the 10 th centime (c.) and the weight (related to 50th c. of height) was above the 97 th c. Clinical examination showed cushingoid body image and pubic hair (Tanner 2-3) Both testes had a volume of $3 \mathrm{~mL}$. Bone age was 6 years (Greulich Pyle). Initial endocrinologieal findings and computertomography showed no evidence of tumor. Between the age of 10 and 11 years, growth velocity decelerated dramatically After repeating the endocrinological examinations, the source of the suspected Cushing's disease was located by magnetic resonance imaging. Within the first 5 months after extirpation of an adrenocorticotropin (ACTH)-producing chromophobic pitu-

Correspondence: Dr. Hans-Reinhard Heise, Department of Pediatrics, University of Magdeburg, 39112 Germany itary adenoma, there was a weight reduction of $10 \mathrm{~kg}$ and a catch-up growth of $4.8 \mathrm{~cm}$. Calculated height velocity was $11.5 \mathrm{~cm} /$ year.

10 days before surgery and 4 months after tumor extirpation, blood samples were collected by a pump (Cameda, Sweden) every $20 \mathrm{~min}$, from 20.00 to 01.00 . Values of serum GH were measured by radioimmunoassay (RIA) (Serono Italy). The sensitivity was 0.5 $\mathrm{ng} / \mathrm{mL}$. An arginine test $(0.5 \mathrm{~g} / \mathrm{kg}$ of $10 \%$ arginine $\mathrm{HCl}$ in $0.9 \% \mathrm{NaCl}$ infused $\mathrm{i} / \mathrm{v}$ at a constant rate over $30 \mathrm{~min}$ ) was performed, including measurements of prolactin and insulin. IGF-I and IGFBP-3 were measured by commercial RIA systems.

In overnight profile of spontaneous $\mathrm{GH}$ before operation, serum GH concentrations showed levels between 0.68 and below 0.5 $\mathrm{ng} / \mathrm{mL}(0.574 \pm 0.075)$. Five months after surgery, they were between 1.43 and below 0.5 $\mathrm{ng} / \mathrm{mL}(0.64+0.264)$. Calculated areas under the curves demonstrated no significant statistical differences. On using arginine, $\mathrm{GH}$ raised only marginally $(1.47 \mathrm{ng} / \mathrm{mL})$. We found no evidence of hyperinsulinemia $(<800 \mathrm{pmol} \mathrm{L})$ or hyperprolactinemia ( $40 \mathrm{mU} / \mathrm{L})$. IGF-I (152 $\mathrm{ng} / \mathrm{mL})$ and IGFBP-3 (3.05 mg/L) showed normal and subnormal values respectively.

The inhibitory effect of cortisol on GH is due to increased hypothalamic somatostatin 


\section{Heise et al.}

secretion (2). Despite a clearly accelerated growth rate after tumor removal, we found no significant difference between GH secretion before and after surgery. Arginine, which is thought to stimulate $\mathrm{GH}$ secretion by decreasing hypothalamic somatostatin tone, was unable to normalize the $\mathrm{GH}$ response. We measured normal IGF-I and IGFBP-3 levels after removal of the adenoma. Normal IGF-I and IGFBP-3 levels have been demonstrated in children with Cushing's disease (1). In contrast to GH deficiency in craniopharyngioma, the normal values of prolactin and insulin excluded any influence of these hormones on postoperative catch-up growth. After the dimination of endogenous cortisol, initial catch-up growth may be the result of increased IGF-I bioactivity.

\section{References}

1. Giustina A, Wehrenberg WB. The role of glucocorticoids in the regulation of growth hormone secretion. Mechanisms and clinical significance. Trends Endocrinol Metab 1992; 3: 306-11.

2. Lima L, Arce V, Diaz MI, Presguerres JFA, Devesa J. Glucocorticoids may inhibit growth hormone release by enhancing beta-adrenergic responsiveness in hypothalamic somatostatin neurons. J Clin Endocrinol Metab 1993; 76: 439-44.

3. Bang P, Degerblad M, Thoren M, Schwander J, Blum W, Hall K. Insulin like growth factor (IGF) I and II and IGF binding protein (IGFB) 1, 2, and 3 in serum from patients with Cushing's syndrome. Acta Endocrinol 1993; 128: 397-404. 